\title{
Gangs, Migration, and Crime: The Changing Landscape in Europe and the USA
}

\author{
Scott H. Decker • Frank van Gemert • \\ David C. Pyrooz
}

Published online: 15 October 2009

(C) The Author(s) 2009. This article is published with open access at Springerlink.com

\begin{abstract}
The history of gangs is intertwined with migration. In America, a number of classic studies have reported on the possible causal link between immigration, socioeconomic position, social disorganization, and gang formation. More recently in Europe, the impact of migration on gangs reflects a complex mix of factors that also includes cultural and media influences. In addition, there are other contextual factors such as immigration and population movement that have received less attention, yet condition the relationship between structural factors and the formation of gangs. Processes such as immigration, migration, and resettlement have had an important impact on the transmission of gangs on an international, national, and local scale, often enhanced by the impact of immigration. This article examines the relationship between immigration, culture, and gangs and contrasts European and US research.
\end{abstract}

Résumé L'histoire des gangs est entrelacée avec celle de la migration. En Amérique, plusieurs études classiques ont fait état d'un lien causal possible entre l'immigration, la position socio-économique, la désorganisation sociale et la formation de gangs. Plus récemment en Europe, l'impact de la migration sur les gangs reflète un mélange de facteurs, y compris des influences culturelles et médiatiques. De plus, certains facteurs contextuels comme l'immigration et les mouvements de population, qui ont moins fait l'objet d'étude, conditionnent

\footnotetext{
S. H. Decker $(\bowtie) \cdot$ D. C. Pyrooz

School of Criminology and Criminal Justice, Arizona State University, 411 North Central, Phoenix, AZ 85004, USA

e-mail: Scott.Decker@asu.edu

F. van Gemert

VU University-Amsterdam, kamer 8A-27, De Boelelaan 1105, 1081 HV Amsterdam,

The Netherlands
} 
néanmoins le rapport entre des facteurs structurels et la formation de gangs. Des processus comme l'immigration, la migration et le rétablissement ont eu un impact important sur la transmission des gangs à l'échelle internationale, nationale et locale. Cet article étudie le rapport entre l'immigration, la culture et les gangs, et dresse une comparaison entre la recherche européenne et la recherche américaine.

Keywords Gangs · Immigration · Comparative criminology · Eurogang Research Program $\cdot$ Ethnic culture

Mots clés gangs · immigration · criminologie comparative · Eurogang Research Program $\cdot$ culture ethnique

\section{Introduction}

A consistent feature in criminological studies of immigration has been the formation of gangs among new immigrant groups (Martinez and Lee 2002). The gang literature, especially the classical studies, is replete with references to the role of immigration in gang formation and the establishment of membership parameters (Puffer 1912; Thomas and Znaniecki 1920; Thrasher 1927). For example, Thrasher's (1927) work highlighted the important role that immigrants, especially those of European origin, played not only in the creation of gangs but also in the expansion of gangs in Chicago. He also documented the nature of gangs relative to city immigration and housing patterns, finding that regardless of ethnicity or nation of origin, new gangs continued to form in certain areas of the city. This suggests a series of urban processes such as ethnic succession and employment patterns that play a role in conditioning the effect of ethnicity and immigration on gang formation.

Thrasher's research on the ecology of cities and the "revolving door" of new immigrant groups and gang formation provides a foundation for the present article. Whether it was immigrants of Jewish, Irish, German, Italian, Greek, or Polish descent, there were certain structural and social conditions that made gang formation possible in Chicago. Central to this discussion were cultural influences. For our purposes, we refer to culture as the collection of behaviors and beliefs held by a group that represents their accumulated experiences. We believe that it is important to distinguish between the culture of the native population, as well as ethnic, youth, and immigrant culture. These are concepts that Vigil (2002) vividly described in detail when discussing the role of multiple marginality across four racial/ethnic groups in Los Angeles. In comparing the culture of the group in the country of origin and its fit with the culture in the country of arrival, Vigil concluded that while immigration and culture is important, disadvantage and marginalization are key "launch" factors for understanding gang formation. As Thrasher's, Vigil's, or any other scholarship on immigration, ethnicity, and gangs will discuss, necessary structural and social elements must be present for gang formation to occur.

This article examines the changing landscape of gangs in Europe and the USA. It is our view that immigration, ethnicity, and culture are important components to understanding this shift, but structural factors act as a conditioning element. There is 
a contextual and social process that is fundamental not only to the changing landscape of gangs in countries but also to gang formation that takes on a "local flavor." Based on a host of qualitative studies, we contend that immigration, ethnicity, and culture matter insofar as fear, mistrust, threat, and conflict are present in the areas where ethnic groups are arriving. Environments that include these factors and the adverse structural conditions described in social disorganization (Bursik and Grasmik 1993; Sampson et al. 1997; Shaw and McKay 1942) and anomie/strain (Merton 1938; Messner and Rosenfeld 2007) theories are breeding grounds for gang formation.

The following article first identifies the diversity of immigration patterns in Europe and the USA. We then discuss definitions of gangs in a global context, emphasizing that comparative gang research is contingent upon consistent definitions of gangs. Then, we address the structural foundations for understanding gang formation, essentially the necessary conditions to be present for groups of individuals to come together. Here, we emphasize how immigration patterns have influenced the European and US gang landscape. We follow this with our discussion of the conceptual underpinnings for putting gang formation in context, arguing that threat and conflict are necessary for gang formation. More importantly, we discuss the role of immigration patterns and culture in shaping how threat, conflict, and fear manifest. Throughout the article, we use research from the Eurogang Research Project because of its use of a common definition of a gang. We conclude with a summary discussion of the research and offer directions for future study.

\section{Europe, the USA, and Immigration}

Both Europe and the USA have a large body of academic research that details the history, patterns, policies, and implications of migration to their continent/country (see, e.g., Hammar 1985; Jacobson 1998). Much of the immigration to Europe comes in different varieties, owing to the historical imperialism of many western European nations. Many of these countries had colonies in Africa, Asia, North America, or South America. Over time, these colonies became independent, most not long after World War II. Due to the special relationship between the colonizers and the colonized, citizens were often free to travel between the European nation and the ex-colony. Many of these groups stayed in the colony nation, for example, England (e.g., India, Pakistan, and West-Indies), France (e.g., Algeria, Morocco, and Senegal), Portugal (e.g., Brazil and Angola), and The Netherlands (e.g., Indonesia and Surinam) have a large - and growing — number of inhabitants with roots in their former colonies.

Much of the immigration patterns over the last half century or so in Europe can be attributed to three factors: economic growth and labor demand, the fall of the Berlin Wall, and asylum seekers fleeing a dangerous or unstable life. First, because the 1960s was characterized by rapid economic growth in Europe (Fetzer 2000), many individuals migrated to fill the labor demand of these expanding nations. During this time, for instance, several northern European countries recruited "guest workers" from Mediterranean countries to help appease the demand for manual labor in factories and mines (Obdeijn et al. 2002). Even though both parties initially thought 
of this arrangement as temporary, many migrants did not leave when they lost their jobs as the economy waned. Second, the fall of the Berlin Wall in 1989 produced a new dynamic in European immigration patterns. The former Soviet Union changed its position regarding the western world, introducing a new direction of population movement (Andreas and Snyder 2000). And third, another category of immigrants, mainly from African countries, the Middle East, and China, sought asylum in European countries. While the motives for immigration varied, they included some seeking refuge from dangerous situations, and others migrating for economic reasons (Engbersen et al. 2007; Van Wijk 2006).

In the USA, the immigrants and immigration patterns were different, but the context in which individuals moved to the USA was similar. The early 1900s was characterized by large waves of European immigrants, with roughly $85 \%$ of immigrants' last residence being some Northwestern or Southeastern European nation (Daniels 2002: 122). But in referencing patterns reported by the US Department of Homeland Security, Hirschman and Massey (2008: 1) noted that 5 million new immigrants in the 1970 s was only the "tip of the iceberg," with that number being surpassed in the following two decades. They identify how large waves of immigrants originating from Latin American and Asian countries have ended up in metropolitan areas across the USA. This process occurred as the USA shifted from an industrial economy to a service economy, creating what Wilson (1987) described as an underclass of citizens, often undertrained to deal with the growth and technological advances made in the USA.

It is within this context that American and European cities became a melting pot of ethnicities in metropolitan areas. Many members of these groups, however, were often much like Wilson (1987) described, undereducated and appropriate only for the evaporating industrial or for economically limited menial labor. Also, many of these groups had first-generation children adapting to what has been described as a culture shock. Conflicts between popular culture and mainstream culture created a strain for these new youth (Sellin 1938). In Adamson's (2000: 276) historical review comparing African-American and European-American gangs in the USA, he noted that "[i]mmigrant children, who found themselves caught between old-world communal practices of their parents and the norms of an often hostile host society, frequently got together in corner groups and gangs." In addition, many of the youth (and their parents) were an anathema for existing "native" groups. As a consequence, many viewed the immigration patterns in Europe and the USA essentially were one large component attributable to creating an environment conducive to gang formation.

\section{Defining Gangs in a Global Context}

The definition of gangs has been a difficult task, with many attempts to bring clarity to the issue (Decker and Kempf-Leonard1991; Esbensen et al. 2001; Ball and Curry 1995; Klein and Maxson 2006). The term "gang" is fraught with considerable definitional diversity in American research, a shortcoming that makes research difficult to compare between cities or nations. Without a consensus definition of the term gang, it would be practically impossible to conduct comparative gang research, 
which is something that gang scholars have argued is necessary to advance the field (Klein 2005a). As Short (2006: 323) noted in Hagedorn's volume on the globalization of gangs, "[d]efinitions are important, if for no other reason than, absent clear definitions, it is not clear what is being talked about, analyzed, or related to globalization."

The research produced by the Eurogang Research Project, which has emerged over the last decade, has produced a definitional consensus on this issue. The definition (Klein 2005b) is as follows: A gang is any durable, street-oriented youth group whose involvement in illegal activity is part of their group identity. While this might not please those concerned with the tautological argument (Katz and JacksonJacobs 2004; Short 1990), as Klein and Maxson (2006: 8; italics in original) pointed out (1) "because gangs vary so widely in their criminal orientations and involvements, they can be studied without circularity" and (2) "crime is not the only aspect we study and predict." The Eurogang definition was applied with equal fidelity by survey and ethnographic researchers, demonstrating its versatility. In addition, the definition was found to be valid and reliable when used to survey policymakers about the nature and extent of the gang problem.

Esbensen and Weerman's (2005) research revealed that there was variation in the levels of gang membership across European nations, with The Netherlands, Germany, and Russia generally having higher levels of membership. In addition, Salagaev et al. (2005) report that Russian schoolchildren reported greater membership in gangs than Dutch schoolchildren, with the latter more comparable to US students. The consensus definition made this research possible. Gang research is limited to the extent that individual explorations of gangs and gang membership employ a consistent working definition. Without this, scholars are put back on their heels, leaving one to regularly question the generalizability of the research based on whether one study includes or excludes "crime." Stated another way, without a consistent gang definition, we cannot begin to compare the organizational differences between the gangs of South and East Los Angeles, let alone compare American gangs with the gangs of Europe.

\section{A Structural Foundation for Understanding Gang Formation}

Gangs have a much longer history of research in the USA than in Europe. Klein (2001a, b: 211) stated that in Europe, "[b]adly needed at this point is some sense of the economic, geographic, and demographic parameters of European cities that might make them more and less vulnerable to street gang formation." While the theoretical foundation for gang formation in the USA is more developed-although macro-level empirical testing is still limited-new conceptual development is in order in both country and continent. As a result, this section relies largely on the USA gang literature.

According to Curry and Decker (2002), there were four major periods of gang presence in the USA - the 1890s, 1920s, 1960s, and 1990s. Each of these periods was marked by significant social changes, with increased immigration being one of them. Covey (2003) supported their analysis and noted that the movement of immigrant groups to the USA led to the growth in gangs in both the early and late 
part of the twentieth century. Covey identified similar migratory patterns in Western Europe. But while immigration is important to the ebb and flow of gang formation and gang membership rates in cities, it has not typically been identified as a cause of gang activity (i.e., formation or membership). Most theoretical explanations for the presence of gangs in cities revolve around economic disadvantage.

While Thrasher (1927) devoted an entire chapter to race, ethnicity, and nationality, he did not inject that language into his definition of gangs or his explanation of how gangs form. His Chicago School colleagues, Shaw and McKay (1942), laid the theoretical foundation for gang formation in the social disorganization tradition. As told by Shaw and McKay and other social disorganization theorists (e.g., Bursik and Grasmik 1993; Sampson 1991; Sampson and Groves 1989), economic disadvantage, racial/ethnic heterogeneity, and residential mobility are key components to the perspective. Sampson et al. (1997) took the research a step further by contending that the previously mentioned concepts matter insofar as they inhibit a community's capacity to impose social control, thus reducing collective efficacy within the community.

Gangs may also form in response to strain or anomie (Merton 1938; Messner and Rosenfeld 2007). Imposing a consistent definition of success and limiting the opportunity structure to obtain that success create a set of unrealistic success goals. Cohen (1955) and Cloward and Ohlin (1960), in two of the most frequently cited pieces on gang formation, put forth similar arguments (see also Miller 1958; Whyte 1943). Anomie/strain conceptions of gang formation, similar to social disorganization perspective, hold that economic disadvantage or poverty is a key component and that gangs form in response to a blocked opportunity structure. In other words, the gang forms and creates a realignment of what constitutes success and the legitimate means to becoming successful.

Most notably, structural changes can result in changes to gangs, which is important to understand because of the ebb and flow of gang activity in America described by Curry and Decker (2002) and Covey (2003). But these structural components are not enough for gangs to form per se. In other words, macro-level explanation needs micro-level context. Whether we are talking structural covariates and correlational or causational relationships, the contextual process of formation is necessary to provide meaning to structural explanations. The following section puts forth a micro-level theory of gang formation-rooted in group threat/group conflict. However, this is not something that can be done without first considering the role of immigration and culture in shaping how gangs form in both the USA and Europe.

\section{The Conceptual Underpinnings of a Changing Gang Landscape: Migration in the Context of Threat/Conflict}

Micro-social context is something that Short (1998) argued is necessary for the field of criminology to bridge the gaps between individual and macro-levels of explanation. It is within this realm we argue that to understand the changing nature of gangs in the USA and Europe, it is necessary to understand the processes by which gangs form as well as the changes that "trigger" those processes. In 
Thrasher's (1927: 46 emphasis added) seminal work, he identified that gangs are "originally formed spontaneously, and then integrated through conflict." Drawing upon this statement, the ties between group conflict, fear, and threat are abundant in cities characterized by an influx of a new ethnic population, especially in communities and neighborhoods that are more economically disadvantaged.

In a review of European- and African-American gang histories, Adamson (2000) argued that structural factors (e.g., government policies, housing and segregation, and labor) were integral components to understanding the nature of gangs since the late eighteenth century. But he also noted that "defensive localism" was the mechanism behind much of the gangs' conflicts; gangs often fought to protect territory, and ethnic gangs would band together if a common enemy was present. Equally, ethnic gangs would fight one another. This was especially important for the European ethnic immigrant groups and was much like what was described by Thrasher (1927: 132) about "old world antagonisms" that carried over in the persistent conflict between Jewish and Polish youth. Thrasher included a story detailed by a social worker about Jewish-Polish conflict in the summer of 1921, where youths were attacked for simply walking in the rival ethnic group's territory. This violence and conflict served a purpose, drawing the members closer to one another and heightening the cohesiveness and thus the purpose of the group.

Comparable to Adamson's defensive localism perspective, Pinderhughes's (1997) research on racial and ethnic tensions in New York City in the late 1980s and early 1990s looked at threat and conflict at a neighborhood level. Pinderhughes first discussed the dynamics of New York and the ever-shifting housing and residential trends. While discussing neighborhoods in the Bronx, South Brooklyn, and Harlem, it was made clear that the African-American and Puerto Rican housing stock of today was the Italian's and Jewish residences of yesterday. Focusing on firstgeneration ethnic Whites (Albanians), second- and third-generation ethnic Whites (Italians), African-Americans from a housing project, and Puerto Rican and Domincan youth, Pinderhughes painted a picture of racial and ethnic isolation being a major cause of the problems in the high schools and streets of New York City. More importantly, Pinderhughes reported on gang-like groups, such as the Albanian Boys and the Avenue T Boys, who apparently formed to ensure respect for their minority group and to "defend" their neighborhood from outsiders. The Albanian Boys and the Avenue T Boys would often attack people of the "wrong color" in their neighborhood, with the latter group describing these assaults as "missions." Pinderhughes described these attacks as cohesion building, basically reinforcing a tough image of the individual under the guise that it protects the community. Pinderhughes (1997: 138) also emphasized that African-American project youth exercised "restraint in East Harlem," notwithstanding profit-oriented crimes (e.g., robbery). But (footnote 5: 183), he said that the African-American and White youth lived in very different neighborhoods and have differences in physical structure, as well as socio-economic and cultural conditions. White youths used the projects, among other structurally changing dynamics, as a rallying cry to attack African-Americans and other minorities to save the "sanctity" of their neighborhood.

The above depiction, in many ways, is quite similar to what Short (1963) and Strodtbeck and Short (1964) found when researching White and African-American gangs in Chicago. Their Chicago research revealed a considerable amount of inter- 
gang, inter-racial violence in the Bridgeport neighborhood, also confirmed in Adamson's (2000) research. This neighborhood was in the cross-hairs of racial change and that change was met with resistance. To explain how group processes facilitate delinquency, Short and Strodtbeck referred to this type of delinquency as being a product of aleatory risk or that risk which is the product of luck or cannot be anticipated. Youth make a brief but calculated decision to act with the group and to act out against status threats because image and respect was so important to maintain. Especially when a target is established, it is necessary for the group to respond. These tactics and conflicts are often what sustains the group, much like what Pinderhughes described for the Italian youth in Bensonhurst. Support for this perspective also comes from Alonso's (2004) and Davis's (2006) research on African-American gang formation in Los Angeles. From the 1930s on, South Los Angeles encountered major population changes, with large waves of African-Americans arriving from the southern regions of the USA. Both authors discussed how this influx was met with resistance. White gangs formed in response to the growing encroachment of African-American families in South Los Angeles.

No matter what the characteristics of the individuals that come together are to form gangs, cultural aspects are central to this discussion. As Strodtbeck and Short (1964) pointed out, for marginalized youth in marginalized neighborhoods, there is the "culture and the consequence." Terms such as "aleatory risk" would not make much sense without understanding the context behind it. For example, Miller (1958) discussed the importance of how lower class culture generates gang delinquency via an inculcation of focal concerns. The values such as toughness and street smarts are normal to lower class youth just as values of family and honor were normal to the Albanian youth in Pinderhughes' study.

\section{Culture, Migration, and Marginalization}

In light of the above discussion of threat/conflict, especially in the context of new immigrant groups, culture is critical. When talking about culture, we are referring to shared norms, values, codes, and meanings of group, in short, the "worldview" of the group. Cultures are reactive and adaptive, and the cultural shock that many youth experience puts them in an odd position. Stay loyal to family or adapt to the dominating culture? This is a question that many ethnic minority and immigrant youth encounter during adolescence. But this is especially common among firstgeneration immigrant youth, and many of these youth resort to gangs of similarly situated, as well as similarly cultured ethnic others.

For example, Van Gemert's (2005) research on Moroccan and Turkish immigrant youth in Amsterdam documents that compared to Turkish youth, Moroccan boys are significantly over-represented in police statistics. Moreover, $60 \%$ of gang members are reportedly Moroccan. This suggests that despite similarities in immigration status and marginalization, Turkish and Moroccan boys take different paths with regard to delinquent and gang involvement. Van Gemert attributed this to cultural differences. Other research has confirmed these findings (Blom et al. 2005; Junger 1990). Van Gemert (1998) pointed out that these groups had very similar immigration histories, lived in the same neighborhoods, and often went to the same schools, yet one ethnic 
group was more gang-involved than the other. There is a similar situation in the USA, where there are a disproportionately larger number of Latino, Asian, and African-American youth reported in survey and officially record statistics on gang membership (Esbensen and Winfree 1998; National Youth Gang Survey 2009).

To explain these disparities, Vigil $(1988,2002)$ proposes the multiple marginality thesis. From this perspective, youth who are marginalized by poverty, poor schools, inadequate parenting, and racism will form and join gangs. But each culture adapts differently, which could explain why Moroccan youth engage in gang activities and why Turk youth abstain. In Pinderhughes' (1997) study, the Albanian males felt compelled to fight back against the African-American, Italian, and Puerto Rican youth bullying them.

Weitekamp et al. (2005) provided a description of the role of culture and ethnicity in gangs in the European context. Weitekamp and his colleagues examined the repatriation of Russians of German descent. Germans who migrated to Russia during the post-World War II separation of Germany into East and West are referred to as "Aussiedler." The repatriation was fraught with irony, as the former German citizens had lost most of their language, customs, and relationships with Germany. Indeed, in many ways, these Germans were more Russian than German, and their transition to Germany has been similar to that of many immigrant groups new to a country or culture. These repatriated Germans engaged in a large number of fights with other Germans and ethnic groups. Their ethnic origins were important to group formation, with most gang membership belonging to a group with members of their ethnic origin. Compounding these affiliational patterns is the social, economic, and cultural deprivation faced by Aussiedlers who returned to their "native" country. These individuals also fit the pattern of double marginality identified by Vigil (1988) for Mexican-Americans in Southern California. Aussiedlers are neither fully German nor Russian, and as such find cultural and economic integration into mainstream German society to be quite difficult, a close parallel to the experiences of other ethnic groups in America (Vigil 2002).

Culture is more than ethnicity and can be confounded with street culture, subculture, and global youth culture. In any case, culture has been the chief explanation given to explain how we find Crips in The Netherlands (Van Gemert 2001) and the A and B gangs in Oslo (Lien 2001). Both Van Gemert and Lien depend on cultural explanations to account for the presence of gangs with American roots in these northern European nations. In particular, the role of the media in the cultural transmission of symbols is a key to understanding how such groups take their affects from such gangs. Despite the similarity in names and gang style, there are important differences between Crips in the USA and Crips in The Netherlands. The latter are far less organized, are not organized around drug sales, are not territorial, and engage in much lower levels of violence. In other words, European Crips have more in common with Crip gang style and affectation than organization or behavior.

Maxson (1998) explained how the problems of traditional gangs from Chicago and Los Angeles ended up on the doorsteps of police stations in suburban and rural America. She first pointed out that gang members who come from another city have little effect on the formation of new gangs; rather, she emphasized that these problems are most often homegrown. To explain the diffusion of gang culture 
across cities, Maxson, while acknowledging that some migratory patterns do take place, attributed this phenomenon more to media popularity. Maxson (1998: 9) wrote that kids today are "hardly dependent on direct contact with gang members for exposure to the more dramatic manifestations of gang culture, which is readily accessible in youth-oriented television programming, popular movies, and the recent spate of 'tell-all' books from reputed gang leaders."

Hagedorn $(2005,2008)$ also identified a global context for gangs. Media reports, videos, and social networking facilitate the dissemination of gang culture. American gang life - among other cultural adaptations - has become a source of behavior that is culturally translated to and emulated by youth in many countries of the world. Hip hop culture and gang culture are seen as particularly acute challenges to traditional values. This culture is readily copied throughout the world: How else did Crips end up in The Netherlands? Why else would we see Liberian child soldiers throwing gang signs from American gangs in front of cameras? While Maxson's (1998) research did not find evidence of purposive gang member diffusion, there may be a case for international gang member migration, particularly when it comes to gang styles rather than gang substance.

The transnational aspect of gangs and cultural diffusion has received a considerable amount of attention. Brotherton (2007) found links between Latin Kings in the USA and fellow gang members abroad, while Feixa et al. (2008) found evidence of gang culture diffusion. The growth and violence of MS-13, Mara Salvatrucha, and 18th Street has spurred much of the transnational attention (Franco 2008). The Los Angeles-based gangs are reputed to be present in many American states, as well as a number of other countries (Savenije 2009). Some believe the deportation of Los Angeles gang members with criminal records has brought the problem to Central America. Using these immigrants, new franchise organizations of MS-13 are brought to different corners of the USA (Johnson and Muhlhausen 2005; Papachristos 2005). This position is countered by others who point to poor conditions and endemic violence in El Salvador that created a situation where American gangs were seen as attractive role models for members of already existing local gangs (pandillas; Coutin 2007; Cruz 2007; Savenije 2009). And thus, the cultural images of the American gangs were imported and adapted to local culture. It still remains to be seen to what extent the emergence of transnational gangs is the outcome of a coordinated movement of gang members. Indeed, as McGuire (2007: 27) stated, it may be "movement not so much of members but of gang style and practices." While deportation may have played a role, the diffusion of gang culture - practices, symbols, and ideas - appears to be part of its subsistence.

\section{Culture, Gangs, Similarities and Differences: Findings from the Eurogang Research}

A combination of structural factors (poverty, disadvantage, and immigration), process factors (cultural conflict and racial and group threat), and cultural factors has resulted in the growth and proliferations of gangs into new areas. One product of such factors has been an increased marginalization of immigrant youth. The Eurogang platform provided an ample opportunity for comparative gang research. 
One of the areas of comparative research that scholars find interesting is examining gang organizational structure differences between cities, regions, and countries. For example, Maxson and Klein (1995) identified five different types of gang structure. They argued that six key features distinguish these types: the presence of subgroups, size, age range, duration of existence, territoriality, and offender versatility. Decker (2001) found that gangs vary considerably along dimensions of structure, organization, and behavior. Structure and organization, to be sure, has a distinct effect on the behavior of gangs and their respective members.

Dekleva (2001), Gatti et al. (2005), Gruter and Versteegh (2001), Lien (2001, 2005), Mares (2001), Salagev (2001), Tertilt (2001), Van Gemert and Fleisher (2005), and Weitekamp et al. (2005) all reported on differing gang organizational and structure characteristics among gangs across and variety of European countries. Collectively, these studies have shed light on gangs in Amsterdam, The Netherlands; Frankfurt, Germany; Genoa, Italy; The Hague, The Netherlands; Morocco, Manchester, Britain; Oslo, Sweden; Russia; and Slovenia. This research has revealed a large amount of heterogeneity of the gangs stemming from the Eurogang summit. The diversity of European gangs is very similar to the USA, where gangs and gang members vary considerably with respect to violence, structure, organization, delinquency, gender, race/ethnicity, culture, and status.

While there is diversity across these gangs and studies, there are not enough comparative studies of cities and countries to allow for full conclusions to be drawn. However, Weerman and Esbensen (2005) conducted one of the first cross-national studies of studies. They captured the structure and characteristics of gangs in The Netherlands and the USA in great detail, providing an interesting contrast. Compared to the gang in The Netherlands, American gangs generally are larger by a factor of two and tend to be much more organized (e.g., symbols, initiation rites, leaders, rules, and meetings). Similarly, both Dutch and American gangs had subgroups, as well as female members. Perhaps the most important comparison is that levels of gang involvement and delinquency were comparable.

\section{Conclusions}

Patterns of population movement and immigration have had specific political, economic, and cultural consequences. In the second half of the previous century, the need for labor in the expanding Western European economies brought many immigrant groups to rather racially homogenous national populations. In addition, an influx of refugees and asylum seekers due to global instability, as well as population movement after the fall of the Berlin Wall and the end of Communism in Central and Eastern European countries, brought a game-changing number of ethnically and culturally different groups. These forces produced important changes in European demographics. As a result, in the last decades, European countries are occupied by young inhabitants that are second-generation ethnic minorities. This has resulted in a multi-ethnic, multi-cultural society in many of these countries.

Just as is the case in the USA, street gangs and troublesome youth groups have grown and proliferated in Europe. Popular responses to this problem have laid the blame on the transmission of gang culture via internet and news mediums. While 
this is the case to an extent, there are other, larger patterns that emerge, very similar to the gang situation in the USA. One commonality between Europe and America is that they both experience a wide variety of structures and ethnicities who became involved in gangs; thus, it cannot be attributed to one ethnic or cultural group. Another that has emerged is that turf and territory also vary in importance. Many gangs do indeed fight for territory, while others are not particularly territorial. In addition, many groups do not have a name, nor do they identify as gang members, while others self-identify as gangs and have names based on locality or are inspired by American gangs. The lack of a common definition has hindered development of truly comparative studies of gangs in the international context. In addition, while there are annual surveys in the USA that establish a baseline of knowledge about gangs, gang members, and gang crime, there are no European counterparts, further hindering the ability to conduct comparative research.

While gangs exhibit heterogeneity with respect to a number of characteristics, something must be said about this heterogeneity. What causes it? Why are there such differences? Questions like these have no other choice but to lead back to the root causes of gangs, and these root causes have direct policy relevance. Gangs differ as a result of structural/macro and contextual/micro-factors. Poverty, immigration, population movement, class, capitalism and anomie/strain, collective efficacy, informal social control, multiple marginalization, racism, racial/ethnic heterogeneity, housing restriction, segregation, and concentrated disadvantage are all major structural components. Each one of these factors contributes to the unfortunate end product - the gang and its structure.

Factors of equal importance that take on a "local flavor" include how a gang forms, contextual/micro-factors such as threat and contagion (Decker 1996), conflict, fear, defensive reaction formation (Alonso 2004), aleatory risk (Strodtbeck and Short 1964), and defensive localism (Adamson 2000), which all played instrumental roles in how gangs form in cities. More importantly, as the dynamics of a city change and as things move away from "the norm," threatened groups react and adapt. Sometimes it results in no action. Other times there are consequences to these shifts. Immigrant groups in Europe are adapting to the new climate created by the native population. In any case, European cities and population groups will adapt to the newcomers and vice versa. Over the course of time, as the immigrants assimilate and native groups provide acceptance, things will change. But if major class differences persist and structural conditions shift, then similar to the USA, expect more years of gang presence in European cities. And perhaps, expect a gang presence to be extended to rural and suburban areas, much like the USA.

Open Access This article is distributed under the terms of the Creative Commons Attribution Noncommercial License which permits any noncommercial use, distribution, and reproduction in any medium, provided the original author(s) and source are credited.

\section{References}

Adamson, C. (2000). Defensive localism in white and black: A comparative history of EuropeanAmerican and African-American youth gangs. Ethnic and Racial Studies, 23(2), 272-298. 
Alonso, A. A. (2004). Racialized identities and the formation of black gangs in Los Angeles. Urban Geography, 25, 658-674.

Andreas, P., \& Snyder, T. (2000). The wall around the West: State borders and immigration controls in North America and Europe. Lanham: Rowman and Littlefield.

Ball, R., \& Curry, G. D. (1995). The logic of definition in criminology: Purposes and methods for defining "gangs". Criminology, 33, 225-245.

Blom, M., Oudhof, J., Bijl, R. V., \& Bakker, B. F. M. (2005). Verdacht van criminaliteit; Allochtonen en autochtonen nader bekeken. Den Haag: WODC.

Brotherton, D. C. (2007). Proceedings from the transnational street gang/organization seminar. Crime, Media and Culture, 3, 372-381.

Bursik, R. J., Jr., \& Grasmik, H. G. (1993). Neighborhoods and crime: The dimensions of effective community control. New York: Lexington.

Cloward, R. A., \& Ohlin, L. E. (1960). Delinquency and opportunity: A theory of delinquent gangs. New York: Free Press.

Cohen, A. K. (1955). Delinquent boys: The culture of the gang. New York: Free Press.

Coutin, S. B. (2007). Nations of emigrants: Shifting boundaries of citizenship in El Salvador and the United States. Ithaca: Cornell University.

Covey, H. C. (2003). Street gangs throughout the world. Springfield: Charles C. Thomas Press.

Cruz, J. M. (2007). Street gangs in Central America. San Salvador: UCA.

Curry, G. D., \& Decker, S. H. (2002). Confronting gangs: Crime and community. Los Angeles: Roxbury.

Daniels, R. (2002). Coming to America: A history of immigration and ethnicity in American life (2nd ed.). New York: Harper Collins.

Davis, M. (2006). City of quartz: Excavating the future in Los Angeles. New York: Verso.

Decker, S. H. (1996). Collective and normative features of gang violence. Justice Quarterly, 13, $243-264$.

Decker, S. H. (2001). The impact of organizational features on gang activities and relationships. In M. W. Klein, H. J. Kerner, C. L. Maxson \& E. G. M. Weitekamp (Eds.), The Eurogang paradox: Street gangs and youth groups in the U.S. and Europe. Dordrecht: Kluwer.

Decker, S. H., \& Kempf-Leonard, K. (1991). Constructing gangs: The social definition of youth activities. Criminal Justice Policy Review, 5, 271-291.

Dekleva, B. (2001). Gang-like groups in Slovenia. In M. W. Klein, H.-J. Kerner, C. L. Maxson \& E. G. M. Weitekamp (Eds.), The Eurogang Paradox: Street gangs and youth groups in the U.S. and Europe (pp. 273-283). Dordrecht: Kluwer.

Engbersen, G., van der Leun, J., \& de Boom, J. (2007). The fragmentation of migration and crime. In M. Tonry \& C. Bijleveld (Eds.), Crime and justice. A review of research (pp. 389-452). Chicago: University of Chicago Press.

Esbensen, F.-A., \& Weerman, F. M. (2005). Youth gangs and troublesome youth groups in the United State and the Netherlands: A cross-national comparison. European Journal of Criminology, 2, 5-37.

Esbensen, F.-A., \& Winfree, L. T., Jr. (1998). Race and gender differences between gang and nongang youths: Results from a multisite survey. Justice Quarterly, 15, 505-526.

Esbensen, F.-A., Winfree, L. T., Jr., He, N., \& Taylor, T. J. (2001). Youth gangs and definitional issues: When is a gang a gang, and why does it matter? Crime and Delinquency, 47, 105-130.

Feixa, C., Canelles, N., Porzio, L., Recio, C., \& Giliberti, L. (2008). Latin kings in Barcelona. In F. van Gemert, D. Peterson \& I.-L. Lien (Eds.), Street gangs, migration and ethnicity (pp. 63-78). Cullompton: Willan.

Fetzer, J. S. (2000). Public attitudes toward immigration in the United States, France, and Germany. Cambridge: Cambridge University Press.

Franco, C. (2008). The MS-13 and 18th Street gangs: Emerging transnational gang threats? http://assets. opencrs.com/rpts/RL34233 20080130.pdf. Accessed July 14, 2009

Gatti, U., Angelini, F., Marengo, G., Melchoirre, N., \& Sasso, M. (2005). An old-fashioned youth gang in Genoa. In S. H. Decker \& F. M. Weerman (Eds.), European street gangs and troublesome youth groups. Lanham: Alta Mira.

Gruter, P., \& Versteegh, P. (2001). Towards a problem-oriented approach to youth groups in The Hague. In M. W. Klein, H.-J. Kerner, C. L. Maxson \& E. G. M. Weitekamp's (Eds.), The Eurogang Paradox: Street gangs and youth groups in the U.S. and Europe (pp. 137-144). Dordrecht: Kluwer.

Hagedorn, J. (2005). The global impact of gangs. Journal of Contemporary Criminal Justice, 21, $153-169$.

Hagedorn, J. (2008). A world of gangs; Armed young men and gangsta culture. Minneapolis: University of Minnesota Press.

Hammar, T. (1985). European immigration policy: A comparative study. Cambridge: Cambridge University Press. 
Hirschman, C., \& Massey, D. S. (2008). Places and peoples: The new American mosaic. In D. S. Massey (Ed.), New faces in new places: The changing geography of American immigration (pp. 1-21). New York: Russell Sage Foundation.

Jacobson, D. (1998). The immigration reader: American in a multidisciplinary perspective. New York: Wiley.

Johnson, S., \& Muhlhausen, D. B. (2005). North American transnational youth gangs: Breaking the chain of violence. The Heritage Foundation. http://www.heritage.org/Research/UrbanIssues/bg1834.cfm. Accessed July 13, 2009.

Junger, M. (1990). Delinquency and ethnicity: An investigation on social factors relating to delinquency among Moroccan, Turkish, Surinamese and Dutch boys. Deventer: Kluwer.

Katz, J., \& Jackson-Jacobs, C. (2004). The criminologists' gang. In C. Sumner (Ed.), The Blackwell companion to criminology (pp. 91-124). Malden: Blackwell.

Klein, M. W. (2001a). Other gang situations in Europe. In M. W. Klein, H.-J. Kerner, C. L. Maxson \& E. G. M. Weitekamp (Eds.), The Eurogang paradox: Street gangs and youth groups in the U.S. and Europe. Dordrecht: Kluwer.

Klein, M. W. (2001b). Other gang situations in Europe. In M. W. Klein, H.-J. Kerner, C. L. Maxson \& E. G. M. Weitekamp (Eds.), The Eurogang paradox: Street gangs and youth groups in the U.S. and Europe (pp. 93-114). Dordrecht: Kluwer.

Klein, M. W. (2005a). The value of comparisons in street gang research. Journal of Contemporary Criminal Justice, 21, 135-152.

Klein, M. W. (2005b). Introduction. In S. H. Decker \& F. M. Weerman (Eds.), European street gangs and troublesome youth groups. Lanham: Alta Mira.

Klein, M. W., \& Maxson, C. L. (2006). Street gang patterns and policies. New York: Oxford University Press.

Lien, I.-L. (2001). The concept, honor, conflict, and violent behavior among youths in Oslo. In M. W. Klein, H.-J. Kerner, C. L. Maxson \& E. G. M. Weitekamp (Eds.), The Eurogang paradox: Street gangs and youth groups in the U.S. and Europe (pp. 165-174). Dordrecht: Kluwer.

Lien, I.-L. (2005). Criminal gangs and their connections: Metaphors, definitions and structures. In S. H. Decker \& F. M. Weerman (Eds.), European street gangs and troublesome youth groups (pp. 31-50). Lanham: Alta Mira.

Mares, D. (2001). Gangstas or lager louts? Working class street gangs in Manchester. In M. W. Klein, H.-J. Kerner, C. L. Maxson \& E. G. M. Weitekamp (Eds.), The Eurogang Paradox: Street gangs and youth groups in the U.S. and Europe (pp. 153-164). Dordrecht: Kluwer.

Martinez, R., \& Lee, M. T. (2002). On immigration and crime. Washington, D.C.: National Institute of Justice.

Maxson, C. L. (1998). Gang members on the move. Washington, DC: U.S. Department of Justice, Office of Juvenile Justice and Delinquency Prevention.

Maxson, C. L., \& Klein, M. W. (1995). Investigating gang structures. Journal of Gang Research, 3, 33-40.

McGuire, C. M. (2007). Working paper on Central American youth gangs in the Washington D.C. area. Washington Office on Latin America (WOLA). http://www.wola.org/index.php?option=com_content\& task=viewp\&id=272\&Itemid=2 Accessed February 5, 2008.

Merton, R. K. (1938). Social structure and anomie. American Sociological Review, 3, 672-682.

Messner, S. F., \& Rosenfeld, R. (2007). Crime and the American dream (4th ed.). Belmont: Wadsworth.

Miller, W. B. (1958). Lower class culture as a generating milieu of gang delinquency. Journal of Social Issues, 14, 5-19.

National Youth Gang Center (2009). National youth gang survey analysis. http://www.iir.com/nygc/nygsa/. Accessed July 13, 2009.

Obdeijn, H., De Mas, P., \& Hermans, P. (2002). De Geschiedenis van Marokko. Amsterdam: Bulaaq.

Papachristos, A. V. (2005). Gang world. Foreign Policy, 147, 49-55.

Pinderhughes, H. (1997). Race in the hood: Conflict and violence among urban youth. Minneapolis: University of Minnesota Press.

Puffer, J. A. (1912). The boy and his gang. New York: Houghton-Mifflin.

Salagev, A. (2001). Evolution of delinquent gangs in Russia. In M. W. Klein, H.-J. Kerner, C. L. Maxson \& E. G. M. Weitekamp (Eds.), The Eurogang paradox: Street gangs and youth groups in the U.S. and Europe (pp. 195-202). Dordrecht: Kluwer.

Salagaev, A., Shashkin, A., Sherbakova, I., \& Touriyanskiy, E. (2005). Contemporary Russian gangs: History, membership, and crime involvement. In S. H. Decker \& F. M. Weerman (Eds.), European street gangs and troublesome youth groups: Findings from the Eurogang research program (pp. 169191). Walnut Creek, CA: AltaMira.

Sampson, R. J. (1991). Linking the micro- and macrolevel dimension of community social organization. Social Forces, 70(1), 43-64. 
Sampson, R. J., \& Groves, W. B. (1989). Community structure and crime: Testing social disorganization theory. American Journal of Sociology, 94, 774-802.

Sampson, R. J., Raudenbush, S. W., \& Earls, F. (1997). Neighborhoods and violent crime: A multilevel study of collective efficacy. Science, 277(5328), 918-924.

Savenije, W. (2009). Maras y Barras; Pandillas y Violencia en los Barrios Marginales de Centroamérica. San Salvador: FLACSO.

Sellin, T. (1938). Culture, conflict and crime. New York: Social Science Research Council.

Shaw, C. R., \& McKay, H. D. (1942). Juvenile delinquency and urban areas. Chicago: University of Chicago Press.

Short, J. F., Jr. (1963). Introduction to Frederick Thrasher's the gangs: A study of 1, 313 gangs in Chicago (abridged). Chicago: University of Chicago Press.

Short, J. F., Jr. (1990). New wine in old bottles? In C. Ronald Huff(Ed.), Gangs in America. Newbury Park: Sage.

Short, J. F., Jr. (1998). The level of explanation problem revisited: The American Society of Criminology 1997 presidential address. Criminology, 36, 3-36.

Short, J. F., Jr. (2006). The challenges of gangs in global contexts. In J. Hagedorn (Ed.), Gangs in the global city (pp. 319-344). Urbana: University of Illinois Press.

Strodtbeck, F. L., \& Short, J. F., Jr. (1964). Aleatory risks versus short-run hedonism in explanation of gang action. Social Problems, 12, 127-140.

Tertilt, H. (2001). Patterns of ethnic violence in a Frankfurt street gang. In M. W. Klein, H.-J. Kerner, C. L. Maxson \& E. G. M. Weitekamp (Eds.), The Eurogang Paradox: Street gangs and youth groups in the U.S. and Europe (pp. 181-194). Dordrecht: Kluwer.

Thomas, W., \& Znaniecki, F. (1920). The polish peasant in Europe and America. Chicago: University of Illinois Press.

Thrasher, F. M. (1927). The gang: A study of 1.313 gangs in Chicago. Chicago: University of Chicago Press.

Van Gemert, F. (1998). Ieder voor zich; Kansen, Cultuur en Criminaliteit van Marokkaanse Jongens. Amsterdam: Het Spinhuis.

Van Gemert, F. (2001). Crips in orange; Gangs and groups in the Netherlands. In M. W. Klein, H. J. Kerner, C. L. Maxson \& E. G. M. Weitekamp (Eds.), The Eurogang Paradox: Street gangs and youth groups in the U.S. and Europe. Dordrecht: Kluwer.

Van Gemert, F. (2005). In S. H. Decker \& F. M. Weerman (Eds.), European street gangs and troublesome youth groups. Lanham: Alta Mira.

Van Gemert, F., \& Fleisher, M. (2005). In S. H. Decker \& F. M. Weerman (Eds.), European street gangs and troublesome youth groups. Lanham: Alta Mira.

Van Wijk, J. (2006). Luanda-Hollanda; Irreguliere (asiel)migratie van Angola naar Nederland. Nijmegen: Wolff Legal.

Vigil, J. D. (1988). Barrio gangs: Street life and identity in Southern California. Austin: University of Texas Press.

Vigil, J. D. (2002). A rainbow of gangs: Street life and identity in the mega-city. Austin: University of Texas Press.

Weerman, F. M. \& Esbensen, F. -A. (2005). A cross-national comparison of gangs: The Netherlands and the United States. In S. H. Decker \& F. M. Weerman (Eds.), European street gangs and troublesome youth groups: Findings from the Eurogang research program (pp. 275-310). Walnut Creek, CA: AltaMira.

Weitekamp, E., Kerner, H.-J., \& Reich, K. (2005). Why do young male Russians of German descent tend to join or form violent gangs? In S. H. Decker \& F. M. Weerman (Eds.), European street gangs and troublesome youth groups. Lanham: Alta Mira.

Whyte, W. F. (1943). Street corner society: The social structure of an Italian slum. Chicago: University of Chicago Press.

Wilson, W. J. (1987). The truly disadvantaged: The inner city, the underclass, and public policy. Chicago: University of Chicago Press.

Dr. Scott H. Decker is Professor and Director in the School of Criminology and Criminal Justice at Arizona State University. He received the BA in Social Justice from DePauw University, and the MA and $\mathrm{PhD}$ in Criminology from Florida State University. His main research interests are in the areas of gangs, criminal justice policy, and the offender's perspective. His most recent books include European Street Gangs and Troublesome Youth Groups (Winner of the American Society of Criminology, Division of 
International Criminology Outstanding Distinguished book award, 2006) and Drug Smugglers on Drug Smuggling: Lessons from the Inside (Temple University Press, 2008, CHOICE Academic Press Book of the Year). His forthcoming book (with Hugh Barlow) Criminology and Public Policy: Putting Theory to Work will be published in 2009 by Temple University Press.

Dr. Frank van Gemert is a Professor at VU University in Amsterdam where he works in the Center for Cultural Criminology. He received the PhD in Cultural Anthropology from Amsterdam University. He is Co-Editor of Street Gangs, Migration and Ethnicity (Willan, 2008) and author of Ieder voor Zich (Spinhuis). His main research interests are in the areas of cultural criminology, gangs and youth crime.

David C. Pyrooz is a doctoral student in the School of Criminology and Criminal Justice at Arizona State University. He received the BS and MS (2007) in Criminology from California State University, Fresno. His research interests include life-course criminology, gangs and delinquent networks, and the intersection between theory and policy. He has a forthcoming article in the Journal of Criminal Justice and recently participated in the Eurogang research network meeting held during the $9^{\text {th }}$ annual conference of the European Society of Criminology. 